\title{
Pre-service language teachers' perceptions of professional learning and development resulting from Greek as a Foreign Language teaching placements*
}

\author{
Maria Andria \\ National and Kapodistrian University of Athens. Greece. \\ Universitat de Barcelona. Spain. \\ mandria@phil.uoa.gr \\ maria.andria@ub.edu
}

Received: 25/4/2021

Accepted: 9/12/2021

Published: 31/1/2022

\begin{abstract}
Language teacher education research has convincingly shown that teaching placements can function as an opportunity for pre-service teachers to connect the theoretical knowledge acquired at university with actual classroom practices. Despite the extensive body of empirical research that has been generated in different foreign language education contexts, the Greek context still remains under-investigated. The purpose of the current qualitative and longitudinal study-framed within Interpretative Phenomenological Analysis (IPA) - is to explore how seven pre-service language teachers of Greek as a Foreign Language (L2) reflect on their professional learning, development and growth as a result of their teaching placement at a language school in Barcelona, Spain. Their perceptions were gathered before and after their placements through questionnaires and interviews. Results showed that participants perceived their placement as crucial for their professional learning and development. They regarded reflective practices as having played a key role in their growth as teachers and professionals. The study concludes by discussing some implications for the design and development of L2 Greek teacher education programs.
\end{abstract}

Keywords: pre-service teachers; teacher education; professional development; language teachers; language teacher education; placements

* This research was financially supported by the Greek government's General Secretariat for Research and Innovation (GSRI) and the Hellenic Foundation for Research and Innovation (HFRI) (Code: 1656). The author would like to express her gratitude to the Greek Community of Catalonia for its collaboration in this study. Special thanks to the Language and Education (LED) research group at the Universitat Autònoma de Barcelona and its coordinator Dr Cristina Escobar Urmeneta for sharing their expertise and assisting this project in multiple and valuable ways. 
Resum. Percepcions dels professors d'idiomes en formació sobre l'aprenentatge i el desenvolupament professional a través de pràctiques en l'ensenyament de la llengua grega com a llengua estrangera

La recerca sobre la formació de professorat d'idiomes ha demostrat que les pràctiques docents poden funcionar com una oportunitat perquè els professors en formació connectin els coneixements teòrics adquirits a la universitat amb les pràctiques reals a l'aula. Malgrat l'extens cos de recerca empírica que s'ha generat en diferents contextos d'educació en llengües estrangeres, el context grec encara roman poc investigat. L'objectiu del present estudi qualitatiu i longitudinal —emmarcat en l'anàlisi fenomenològica interpretativa (AFI) - és explorar com set professors en formació del grec com a llengua estrangera (L2) reflexionen sobre el seu aprenentatge, desenvolupament i creixement professional com a resultat de les seves pràctiques en un centre d'idiomes a Barcelona, Espanya. Les seves percepcions es van recollir abans i després de les seves pràctiques mitjançant qüestionaris $i$ entrevistes. Els resultats van mostrar que els participants van percebre les seves pràctiques com una experiència crucial per al seu aprenentatge i desenvolupament professional. L'estudi conclou discutint algunes implicacions per al disseny i desenvolupament de programes de formació de professorat del grec com a L2.

Paraules clau: professors de pràctiques; formació de professorat; desenvolupament professional; professorat d'idiomes; formació de professors d'idiomes; pràctiques

Resumen. Percepciones de los profesores de idiomas en formación sobre el aprendizaje y el desarrollo profesional a través de prácticas en la enseñanza del griego como lengua extranjera

La investigación sobre la formación de profesorado de idiomas ha demostrado que las prácticas docentes pueden funcionar como una oportunidad para que los profesores en formación conecten los conocimientos teóricos adquiridos en la universidad con las prácticas reales en el aula. A pesar del extenso cuerpo de investigación empírica que se ha generado en diferentes contextos de educación en lenguas extranjeras, el contexto griego aún permanece poco investigado. El objetivo del presente estudio cualitativo y longitudinal —enmarcado en el análisis fenomenológico interpretativo (AFI) - es explorar cómo siete profesores en formación de griego como lengua extranjera (L2) reflexionan sobre su aprendizaje, desarrollo y crecimiento profesional como resultado de sus prácticas en un centro de idiomas en Barcelona, España. Sus percepciones se recogieron antes y después de sus prácticas a través de cuestionarios y entrevistas. Los resultados mostraron que los participantes percibieron sus prácticas como una experiencia crucial para su aprendizaje y desarrollo profesional. El estudio concluye discutiendo algunas implicaciones para el diseño y desarrollo de programas de formación de profesorado de griego como L2.

Palabras clave: profesores en prácticas; formación de profesorado; desarrollo profesional; profesores de idiomas; formación de profesores de idiomas; prácticas

\section{Summary}

\section{Introduction 5. Method}

2. Language teacher education for Greek as Foreign/Second Language

6. Results

7. Discussion and conclusions

3. A pilot L2 Greek teacher education

Bibliographical references program in Barcelona

4. Research questions 


\section{Introduction}

The importance of teaching placements as a fundamental part of teacher education programs is widely recognized (Ruiz-Corbella et al., 2019; Zeichner, 1996). Placements offer pre-service teachers the opportunity to connect the theoretical knowledge acquired at university with classroom practice (Carlson, 1999), enabling them to better understand the nature of learning and teaching in a real-life educational setting, while also offering "a protected field of experimentation" (Hascher et al., 2004, p. 623). In other words, placements set the ground for "learning by doing" (Dewey, 1938); they provide a space where pre-service teachers will be exposed to "experiential learning" (Kolb, 1984), and thus develop knowledge and skills through their own hands-on experience (Coiduras et al., 2014, 2017; Good et al., 2006).

In any professional area, the workplace is the primary space in which professional development occurs. For pre-service teachers, placements thus constitute the first space for professionalization (Correa Molina, 2014), since they offer them the opportunity to acquire competences in the teaching profession. More than just an integral part of their education and professional learning (Coiduras et al., 2017), for pre-service teachers placements constitute a link between university and the labor market.

\section{Language teacher education for Greek as Foreign/Second Language}

In Greece, teachers of Greek as a Second or Foreign Language (L2) primarily come from Bachelor's (BA) degrees in Greek Philology and Linguistics, but also from multi-disciplinary degrees such as Philosophy, Psychology and Pedagogy. These BA degree programs are generally oriented towards the education of future language teachers of Greek as a first language (L1) in secondary education. Teaching Greek as an L2 is sometimes offered as an elective course that provides a brief introduction to the topic. Specialization in Teaching Greek as an L2 can be acquired after completion of a BA, via Master's (MA) programs or specific training programs offered by various institutions.

Teaching Greek as an L2 is a relatively new but increasingly popular professional option. Efforts have therefore recently been made to systematize L2 Greek teacher education programs (Andria \& Iakovou, 2021), which have hitherto tended to be heavily theoretical in nature and do not usually include actual L2 teaching practice. In general, Greek universities have traditionally tended to follow a "transmission-based approach and focus mainly on theory rather than practice", an approach that has changed little over the years (Mattheoudakis, 2007, p. 1274). Although the need for innovative pedagogical change (Frydaki et al., 2013) is increasingly acknowledged, Greek undergraduate students doing Greek Philology degrees still have little exposure to actual language classroom practices, with the one-semester "Internship" course they take during the final year of their degree being 
limited to a few classroom observations and no actual hands-on teaching practice. $^{1}$

Fortunately, this lack of placements in Greek BA degrees has to some extent been compensated for in recent years by the European Union's 'Erasmust' program, which supports traineeships abroad for students at BA, MA and $\mathrm{PhD}$ levels. Many Greek students seek the opportunity to gain professional experience through this program before entering the job market.

\section{A pilot L2 Greek teacher education program in Barcelona}

In view of the importance of language teacher education for future L2 Greek teachers, and the potential role of actual classroom practice in this education, the LETEGR2 (LEarning, TEaching and LEarning to Teach in Greek as an L2: Evidence from different learning contexts) research project, funded by the Greek government's General Secretariat for Research and Innovation (GSRI) and the Hellenic Foundation for Research and Innovation (HFRI), set up a pilot teacher education program. The program was based on classroom observation and practice teaching (Lasagabaster \& Sierra, 2004) combined with reflective practices (for more details see Andria, 2020; Iakovou, 2020). The program was intended for (a) students on the University of Athens's MA Program in Teaching Greek as an L2; (b) pre-service teachers who carried out their placements at L2 Greek institutions abroad; and c) in-service L2 Greek teachers in Greece and abroad. Its design was based on the principles of Action Research (whereby the teacher is the researcher) (Altrichter et al., 1993) and Reflective Teaching (Richards \& Lockhart, 1996), and it was inspired by the Bellatera Model for Pre-Service Teacher-Education for Content and Language Integrated Learning developed at the Universitat Autònoma de Barcelona (Escobar Urmeneta, 2010). Language teacher education and professional development here are not understood merely as a way of providing teachers with a repertoire of effective teaching techniques and pedagogical tools. Rather, they are conceived as a lifelong learning process, a trajectory of personal improvement and professional empowerment involving a continuous apprenticeship in the acquisition of new teaching knowledge and competences. The aim of the LETEGR2 pilot teacher education program is thus to guide and engage language teachers with this lifelong learning experience, to educate them in reflective practices, to reinforce teacher cognition (Borg, 2006), and finally to prepare them to "gain sufficient autonomy to be able to take the lead of [their] own education" (Escobar Urmeneta, 2013, p. 350). Reflective practice is defined here as a cognitive process which includes purposeful, metacognitive thinking. It can take place either in-action (i.e., at the time of happening) or on-action (i.e., after a certain experience has occurred) (Schön, 1983). Reflective teaching involves a continuous, systematic review-

1. Here reference is made to degrees in Greek Philology and similar fields, not to degrees in primary education, which do include a placement in Greek primary schools. 
ing process, whereby teachers critically analyze, interpret and understand their classroom practices.

To date, little attention has been paid to investigating the impact of placements on pre-service L2 Greek teachers' professional learning and development. In contrast to the vast body of research on teacher education programs in other target languages such as English or Spanish, the Greek context remains under-explored. For this reason, in 2018 the LETEGR2 program, in collaboration with the Erasmus+ traineeship program, initiated a pilot model for pre-service L2 Greek teachers. This would involve them completing a teaching placement in Greek as a Foreign Language at a private language school offering courses to the general public in Barcelona, Spain. The present study describes the results of a preliminary investigation into how these preservice teachers of L2 Greek perceived the impact of their placement in terms of professional learning. More specifically, because it adopts a longitudinal design by obtaining participant views both before and after the placement period, these results shed light on how teachers' perceptions change and develop as a result of their placement.

\section{Research questions}

The general aim of this study is to investigate Greek pre-service teachers' perceptions of whether and how their placement had an impact on their professional development as language teachers. Perceptions here are understood as participants' thoughts and views on their experience and as part of teacher cognition (Borg, 2006). They are also considered a fluid construct rather than a stable one (Given, 2008). More specifically, the research questions that guide this study are the following:

1. What are pre-service teachers' initial expectations for their placement before they begin?

2. Upon completing their placement, what are pre-service teachers' perceptions of the professional development they have gained as a result of it?

\section{Method}

\subsection{General approach}

The current study adopts the qualitative research paradigm, whereby the researcher endeavors to access the inner thoughts of individual participants (Brown \& Clarke, 2013). More specifically, the study is framed within Interpretative Phenomenological Analysis (IPA), a qualitative research approach whose aim is to examine individuals' meaning-making of significant lived experiences (Smith et al., 2009). IPA draws on the principles of phenomenology and hermeneutics, and views individuals as self-reflective beings who consciously think about their experiences and try to interpret them. Another 
fundamental aspect of IPA is its idiographic nature, in that IPA pays equal attention to each case and each participant.

IPA has been adopted here on the grounds that the present study (a) is concerned with individual experiences and participants' thoughts and reflections on these experiences in a specific context; (b) involves a small sample of largely homogeneous participants; and (c) presents a longitudinal pre-/postdesign intended to offer a "before and after" perspective.

\subsection{Participants}

The participants were seven pre-service teachers who carried out an Erasmus+ placement teaching Greek as an L2 at a language school in Barcelona, Spain. Placements took place in either the 2018-19 or 2019-20 academic year. Participants were all female, with ages ranging from 22 to 27 (mean: 24.5). Six of them carried out a four-month placement, while one of them opted for an eight-month one. ${ }^{2}$ The home university was the University of Athens, with one exception who was studying at the University of Crete. Four participants had just completed their BA degrees, while the other three had just completed a

Table 1. Participants' characteristics

\begin{tabular}{lclcccc}
\hline $\begin{array}{l}\text { Participant } \\
\text { pseudonym }\end{array}$ & $\begin{array}{c}\text { Degree } \\
\text { completed }\end{array}$ & BA Degree & Age & $\begin{array}{c}\text { Year of } \\
\text { placement }\end{array}$ & $\begin{array}{c}\text { Had observed L2 } \\
\text { Greek language } \\
\text { classroom }\end{array}$ & $\begin{array}{c}\text { Had previous } \\
\text { experience } \\
\text { teaching } \\
\text { L2 Greek }\end{array}$ \\
\hline Ariadne & MA & $\begin{array}{l}\text { Greek } \\
\text { Philology }\end{array}$ & 27 & $2018-19$ & Yes & Yes \\
\hline Zoe & BA & $\begin{array}{l}\text { Greek } \\
\text { Philology }\end{array}$ & 24 & $2018-19$ & No & No \\
\hline Cleo & MA & $\begin{array}{l}\text { Philosophy, } \\
\text { Pedagogy } \\
\text { and }\end{array}$ & 27 & $2018-19$ & Yes & No \\
\hline Daphne & BA & $\begin{array}{l}\text { Philosophy } \\
\text { Pedagogy } \\
\text { and }\end{array}$ & 23 & $2018-19$ & No & No \\
\hline Natalia & BA & $\begin{array}{l}\text { Phychology } \\
\text { and Social } \\
\text { Studies }\end{array}$ & 22 & $2019-20$ & No & No \\
\hline Niki & BA & $\begin{array}{l}\text { Greek } \\
\text { Philology }\end{array}$ & 23 & $2019-20$ & No & No \\
\hline Sofia & MA & $\begin{array}{l}\text { Greek } \\
\text { Philology }\end{array}$ & 26 & $2019-20$ & Yes & No \\
\hline
\end{tabular}

Source: Own elaboration.

2. The Erasmus+ program financially supports traineeships abroad for 2 to 4 months. Students can opt for a longer placement, but receive no additional funding. 
two-year MA program in Teaching Greek as an L2. In all cases, BA degrees had been in either Greek Philology $(n=4)$ or in multidisciplinary degrees in Philosophy, Pedagogy and Psychology $(\mathrm{n}=2)$ or Philosophy and Social Studies $(n=1)$. All but one participant had no previous experience of teaching Greek as an L2, although several had observed L1 Greek language classes in Greek secondary schools. Table 1 below summarizes participants' characteristics.

\subsection{Context}

The study took place at a private language school offering courses in Greek in Barcelona, Spain. The language school belongs to a non-profit association whose members are either Greeks living in the area or local philhellenes. The school offers courses for adult learners at several proficiency levels. Students are also given access to various cultural activities organized by the association, such as festivals, conferences, dance courses and cooking workshops, among other things.

\subsection{Structure of the placement}

Prior to the start of the placement, a learning agreement was signed by the home universities in Greece, the host institution in Barcelona and the students, setting out details of the placement, the expected learning outcomes for the student and the student's self-assessment plan. Pedagogical guidance and mentoring for the placement teachers was provided by the school's coordinator of courses, while the president of the association served as overall supervisor and administrator of the placement program.

Placement obligations consisted of designated hours devoted to the following tasks: (a) classroom observation; (b) design and organization of teaching materials; (c) serving as an assistant to the regular teacher; (d) teaching; and (e) assisting with a research project related to L2 Greek. The number of working hours per week was 25. During the first three to four weeks of their placement, placement teachers carried out participant classroom observation, in order to become familiar with the educational context and to gain a better understanding of the courses and the students' profile, motivations and needs. This constituted a fundamental element of the placement, given that for most of the participants this was the first time they had observed an L2 Greek class. During this period, they had the opportunity to observe classes carried out by different teachers-being thus exposed to different teaching styles and methods - and of various proficiency levels. After the first weeks of classroom observation, placement teachers took an increasingly active role in the class, moving from microteaching (Allen \& Ryan, 1969) to ultimately planning and implementing a full class session.

As part of their placement, participants were also required to carry out a set of reflective tasks intended to raise their awareness of pedagogical issues. This consisted of video-recording at least one of the full class sessions they 
taught, viewing the video, then completing a self-assessment and reflection form. The form was designed to help less experienced teachers focus on specific aspects of the lesson such as class management, teaching strategies, teaching objectives and assessment criteria, and then come up with a plan for improvement (for more information on the self-reflection instruments and process see Andria, 2020; Iakovou, 2020).

\subsection{Instruments and data collection}

As described above, the goal of this study was to gather placement teacher reflections prior to and at the end of their placement experience. The instrument used to gather the initial data consisted of a short questionnaire presented in written form on the first day of the placement. It included three open questions asking about: (a) participants' previous experience with L2 Greek courses; (b) their previous teacher placement experiences (if any); and (c) their expectations for the upcoming placement. At the end of the placement, a face-to-face interview took place at which participants were asked a set of questions based on the structure of a previous study by Andria et al. (submitted). Questions solicited participant reactions to and reflections on the host institution, the structure and organization of the placement, their placement experience overall, and their learning outcomes with regard to teaching L2 Greek and professional development overall. (For the complete set of questions, see the Appendix).

Participants were interviewed individually by the researcher in Greek (the L1 of both the researcher and the participants) and audio-recorded. On average, interviews took about 42 minutes. The total length of the compiled recordings was 300 minutes. Before the data collection, all participants provided written informed consent to being recorded and having their input used anonymously for research purposes.

The focus of the current study is restricted to questionnaire responses related to participants' initial expectations, and participant responses to interview questions that elicited retrospective reflections on the contribution made by their placement experience to their professional development as language teachers (in the Appendix, sections B and D, and questions 1 and 5 of section $\mathrm{C}$ ).

\subsection{Data coding and analysis}

The data for analysis had two components: participants' written answers to the preliminary questionnaire and transcripts of the final interviews. The process of data coding and analysis was carried out in three steps, consistent with IPA methodology as outlined by Smith et al. (2009). The first step involved the researcher becoming fully familiar with the data through repeated reading of each transcript and questionnaire. In line with IPA's idiographic nature, the researcher explored each case separately and in depth before moving on to search for patterns across cases. The second step consisted of annotation: the 
researcher read through the data again, this time underlining fragments of interest in the transcript and writing down key words, descriptive comments and exploratory notes on the semantic level. Additional readings led to further annotation at a higher interpretive and conceptual level. The goal of the third and final step was to determine the over-arching themes revealed in the data. Initial notes from step two were grouped into themes, which were then organized, with links between them being traced. This distillation process was applied first for each participant, then across the group as a whole in order to detect shared thematic patterns. In this phase, participants' responses to each specific question were cross-checked for similarities and differences, in an attempt to explore how participants' perceptions of the experience converged or diverged.

\section{Results}

\subsection{Pre-service teachers' initial expectations}

Regarding initial expectations prior to their placement, all participants said that they expected to "acquire experience" as teachers of Greek in "real classroom conditions". Some of them emphasized the importance of this experience as "practical", as opposed to the theoretical training they had received as university students. This expected experience was further qualified by the participants as an opportunity to become familiar with specific methodologies and teaching techniques for Greek as an L2, while learning to cope with the specific challenges that the reality of teaching entails. One participant (Sofia) became even more specific about this aspect, and said that she was expecting to learn about the selection, creation and assessment of teaching materials "beyond theory" and also to be able to understand students' needs. Because their prior experience had been in the context of teaching Greek as an L1, the BA participants also highlighted the importance for them of understanding how teaching Greek as a foreign language would differ from teaching it as an L1. By the same token, participants also mentioned the importance of observing classes and then teaching students from a different country, culture and linguistic background. The only participant who had carried out a previous placement in Greece (Ariadne) said that she was particularly interested in "detecting differences between the different learning contexts (Greek as a second vs. foreign language)". Another participant (Daphne) said that she was expecting to acquire general professional skills, given that this would be her first time in a professional context. More specifically, she mentioned that she was expecting to develop cooperative and communicative skills with her fellow teachers. The same participant also acknowledged that it was fundamental for her to foster intercultural and cultural awareness through her placement.

In the interview at the end of their placements, participants were asked to reflect retrospectively on their initial expectations and thoughts on teaching Greek as an L2. Participants reiterated the ideas that they had expressed in the 
preliminary questionnaire, but were also now able to expand on them. All the participants noted the initial lack of confidence and anxiety (or even "fear" in some cases) that they had felt regarding teaching and class management prior to the placement. According to them, these feelings were mainly due to their lack of professional experience and their young age. Some of them mentioned concerns about dealing with adult learners, afraid that their "authority" as teachers would be called into question because they were younger than their students.

\subsection{Pre-service teachers' perceptions of professional development achieved as a result of their placement}

In the final interviews, participants reflected on their experiences and made a final appraisal. All of them said that their placements had helped them significantly in terms of professional learning and development. The two most important benefits they acknowledged were, first, being able to make the transition from theory to practice, as seen in comments such as: "I obtained practical experience" (Ariadne) or "It helped me move from theory to practice" (Cleo). And second, the opportunity to experience what it meant to be a teacher in real-life conditions.

Participants also highlighted how their placements had raised their awareness of the challenges of the teaching profession, specifically in terms of responsibility, classroom management and the use of pedagogical resources. BA participants also commented that this placement had been a window onto a different world, that of teaching Greek as an L2 to adults, something quite different from what they had been exposed to in classroom observations as undergraduates; in Natalia's words: "This is completely different to being in a secondary school in Greece". They also became aware of the differences between teaching Greek as an L1 and teaching it as an L2, as illustrated in the following quote from Niki:

At first, when I thought about teaching Greek as an L2, I thought "How difficult could that be? I'm Greek, I speak Greek, I'll make it." I thought it would be easier, but once there, it seemed to me far more difficult... I remember the very first day of my classroom observation... I had to introduce myself and I was speaking too fast. And then I realized that I have to pay a lot of attention to the way I speak, the vocabulary I use, etc.

In this excerpt from the interview, it can be seen that, through her placement, this pre-service language teacher has become aware that aspects of how a teacher talks to students, such as pace and content, are very important. Participants also comprehended that teaching a foreign language requires specialized education. As Natalia put it:

I realized that the knowledge that I had from my BA degree was not enough. It was a base, but it was not sufficient for teaching Greek to foreigners. I had to teach a language from scratch and that required concrete knowledge and methodology that I did not possess. 
Those participants who had not yet completed a teaching MA also stated that, prior to their placement, when thinking about teaching foreign languages they drew on their own experiences as language learners, especially of English. This made them view foreign language learning as more exam-oriented and grammar-based, since this was the approach that they had experienced within the Greek L2 educational system. However, through their placement, they came to realize that language teaching is not merely a question of teaching grammar and vocabulary but rather a much more complex task which also involves the teaching of practical and sociocultural content.

When asked whether they felt that a teaching placement should be compulsory for all future teachers of L2 Greek, all but one answered affirmatively. The one participant who answered negatively, albeit recognizing the benefit and value of placements, argued in favor of the placement being optional rather than mandatory. Several interviewees also suggested that such placements should have a duration of more than the four months offered by the Erasmus+ program, and preferably a full academic year. The only participant whose placement had indeed lasted for a whole academic year concurred, saying that the longer duration had allowed her to greatly consolidate her learning and skills.

Several participants lamented the lack of placements in BA programs in Greece. In Daphne's words:

During the placement, you move towards the practical aspect, which I consider extremely important, and it is missing from Greek universities. This practical component is important for the teacher to understand whether he or she actually likes this job, whether he or she wants to pursue it...

Participants also mentioned the importance of this placement as the first contact with a real workplace. Beyond giving them training as classroom teachers, it helped them understand how to operate in a team and make sense of notions such as workplace hierarchy and collaboration.

Something that all participants highlighted was the important role played by reflective practices in their placement. More specifically, they emphasized the impact that video-recording their lesson(s) and the subsequent reflection based on viewing the video had on their professional development. Though some of them confessed to initially feeling a certain level of anxiety about being filmed, they all recognized the valuable insights and learning that this experience offered them. They mentioned that, thanks to this self-observation process, they were able to better understand their classroom practices, reflect on them and come up with ideas about how to improve. The video/reflection task thus constituted for them "a source of knowledge". Participants also emphasized that the reflection form they were asked to complete after watching their videos served to guide them toward more thorough thinking. As Daphne commented: 
I think that without the reflection form, the work that I would have done would have been very superficial. I mean, the form helped me to think about more aspects and to reflect more.

Participants also stated that having their teaching guided with and through reflective practices made them eager to adopt this process in their future professional trajectory as a way of continuous development and lifelong learning. Feedback received from the mentor and from the teaching staff was also highly valued.

Participants also claimed that their placement had changed them in terms of not only professional development but also personal growth. This was reflected in comments such as "I have changed completely, I feel that I'm a different person to who I was before, I needed this experience," (Cleo), "I evolved and I also learned a lot about myself," (Daphne) or "I was helped both as a person and as a teacher." (Niki).

\section{Discussion and conclusions}

The general aim of the present study was to investigate pre-service teachers' perceptions of whether and how a teaching placement had an impact on their professional learning and development as language teachers of L2 Greek. In line with previous studies, results here suggest that pre-service teachers perceive teaching placements as an experience of utmost importance (Coiduras et al., 2014, 2017; Ruiz-Corbella et al., 2019). As positive aspects, participants identified the bridge that the placement represented between theoretical knowledge and classroom practice, as well as the enhanced understanding of the nature of the teaching profession it afforded them (Andria et al., submitted). Consistent with other research (Correa Molina, 2014), participants also noted the value of the placement as their first encounter with a workplace. The findings also confirm the importance of classroom observation for pre-service teachers' education (Lasagabaster \& Sierra, 2006). As reported elsewhere, participants perceived that their placements were conducive to reconsidering their preconceptions and beliefs regarding foreign language teaching, leading to a fuller understanding of the skills and attitudes required by the profession (Andria, 2020; Iakovou, 2020; Mattheoudakis, 2007). Furthermore, the present study corroborates the significance of Reflective Teaching (Schön, 1983) as part of teacher education (Escobar Urmeneta, 2010, 2013). However, these findings also confirm that, to be sufficiently profound and therefore effective, reflective activities need to be guided and supported (Escobar-Urmeneta, 2010; Hascher et al., 2004). Another noteworthy finding concerns the positive emotions that participants reported on completion of their placement. This in itself is an aspect that previous studies have pointed to as being "supportive for professional development" (Hascher et al., 2004, p. 634).

The findings of this study have valuable implications for the design of teacher education programs for L2 Greek. Given the impact that placements 
have been shown to have on future teachers' professional learning and development, the current lack of practical focus in Greek BA and MA degrees is an issue that needs to be thoroughly addressed and re-examined - a finding which is also in line with those documented in other contexts (Barahona, 2016; Cheng et al., 2010; Yang \& Hen, 2010, among others). These results also suggest that teaching placements for future L2 Greek teachers should be based on a solid educational model which includes reflective activities and inculcates a professional mentality of lifelong learning. Teacher education in Greece, especially in regard to teaching Greek as an L2, should be based on a curriculum which balances advanced theoretical knowledge with quality placements. At the same time, the employability of students is also an issue that Greek universities need to take into account, and the hands-on experience afforded by real classroom experience is certainly a step towards the creation of a skilled and therefore highly employable teaching workforce.

Despite this study's contribution to our understanding of the relationship between teaching placements and L2 Greek pre-service teachers' professional learning and development, further research is clearly needed, particularly given the striking lacuna identified in L2 Greek teacher education research. For example, looking beyond perceptions, future studies could explore the real changes in pre-service teachers' knowledge and expertise that result from their placements. Further empirical evidence is of interest not just in itself, but also because it must serve as the foundation for any proposal intended to bring about improvements in teacher education programs.

\section{Bibliographical references}

Allen, D., \& Ryan, K. (1969). Microteaching. London: Addison-Wesley.

Altrichter, H., Posch, P., \& Sомекн, B. (1993). Teachers investigate their work: An introduction to the methods of action research. London: Routledge.

Andria, M. (2020). Learning to teach and teaching Greek as a Second/Foreign Language: A preliminary approach on teachers' and student-teachers' perceptions. In Mackay, J., Birello, M., \& Xerri, D. (Eds.), ELT Research in Action: Bringing together two communities of practice (pp. 49-52). Kent, UK: IATEFL.

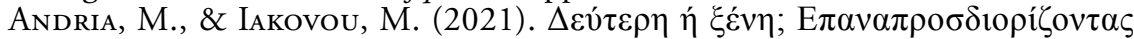

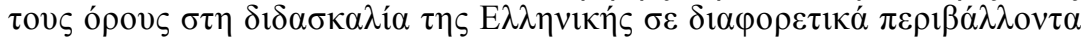

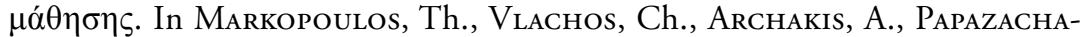
riou, D., Xydopoulos, G.J., \& Roussou, A. (Eds.), Proceedings of the 14th International Conference on Greek Linguistics (ICGL14) (pp. 60-69). Patras: University of Patras.

Andria, M., París, G., \& Escobar Urmeneta, C. (submitted). Primary education student-teachers' perceptions towards pre-service school placement in CLIL settings.

Barahona, M. (2016). English language teacher education in Chile: A cultural historical activity theory perspective. London: Routledge. $<$ https://doi.org/10.4324/9781315689937>

Borg, S. (2006). Teacher cognition and language education: Research and practice. London: Continuum. 
Braun, V. \& Clarke, V. (2013). Successful qualitative research: A practical guide for beginners. London: SAGE.

Carlson, H.L. (1999). From practice to theory: A social constructivist approach to teacher education. Teaches and Teaching: Theory and Practice, 5(2), 203-218. <https://doi.org/10.1080/1354060990050205>

Cheng, M. M. H., Cheng, A. Y. N., \& Tang, S. Y. F. (2010). Closing the gap between the theory and practice of teaching: Implications for teacher education programmes in Hong Kong. Journal of Education for Teaching, 36(1), 91-104. <https://doi.org/10.1080/02607470903462222>

Coiduras, J.L., París, G., Torrelles, C., \& Carrera, X. (2014). La evaluación de competencias en una experiencia de formación dual de maestros: Diferencias y semejanzas entre tutores de escuela y de universidad. Estudios Pedagógicos, 40 (special 2014), 29-48. <https://doi.org/10.4067/s0718-07052014000200003>

Coiduras, J.L., Correa Molina, E., Boudjaoui, M., \& Curto, A. (2017). Formación dual en el grado de educación: claves organizativas y pedagógicas. Qurriculum. Revista de teoría, investigación y práctica educativa, 30, 81-102. Retrieved from <https://www.ull.es/revistas/index.php/qurriculum/article/ view/38/22>.

Correa Molina, E. (2014). Las prácticas: Primer espacio de profesionalización docente. In I. CorTÉs \& C. Hirmas (Eds.), Vinculación entre el sistema universitario y el sistema escolar (pp. 23-38). Chile: OEI.

Dewey, J. (1938). Experience and education. New York: Macmillan Company.

Escobar Urmeneta, C. (2010). Pre-service CLIL teacher-education in Catalonia: Expert and novice practitioners teaching and reflecting together. In D. LASAGABASTER, \& Y. Ruiz de Zarobe (Eds.), CLIL in Spain: Implementation, Results and Teacher Training (pp. 189-218). Cambridge: Cambridge Scholars Publishing.

- (2013). Learning to become a CLIL teacher: Teaching, reflection and professional development. International Journal of Bilingual Education and Bilingualism, 16(3), 334-353. <https://doi.org/10.1080/13670050.2013.777389>

Frydaki, E., Cavoura, Th., Milingou, E.E., \& Fountopoulou, M.Z. (Eds.) (2013).

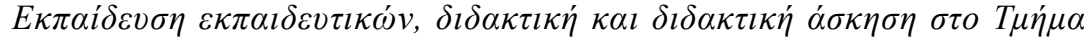

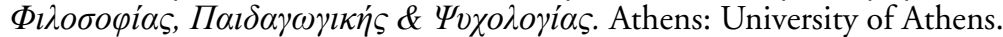

Given, M. L. (Ed.) (2008). The SAGE encyclopedia of qualitative research methods. London: SAGE.

Good, T. L., McCaslin, M., Tsang, H. Y., Zhang, J., Wiley, C. R. H., Rabidue Bozack, A., \& Hester, W. (2006). How well do 1 st year teachers teach. Does type of preparation make a difference? Journal of Teacher Education, 57, 410-430. <http://dx.doi.org/10.1177/0022487106291566>

Hascher, T., Cocard, Y., \& Moser, P. (2004). Forget about theory-practice is all? Student teachers' learning in practicum. Teachers and Teaching: Theory and practice, 10(6), 623-637.

<https://doi.org/10.1080/1354060042000304800>

IAKovou, M. (2020). Classroom observation in second language classrooms: Bridging the gap between theory and practice for pre-service and in-service teachers of Greek as an L2. CLIL Journal of Innovation and Research in Plurilingual and Pluricultural Education, 3(2), 15-36.

$<$ https://doi.org/10.5565/rev/clil.45> 
Kolb, D. A. (1984). Experiential learning: Experience as the source of learning and development. London: Prentice-Hall.

Lasagabaster, D., \& Sierra, J.M. (Eds.) (2004). La observación como instrumento para la mejora de la enseñanza-aprendizaje de lenguas. Barcelona: Horsori.

Mattheheoudakis, M. (2007). Tracking changes in pre-service EFL teacher beliefs in Greece: A longitudinal study. Teaching and Teacher Education, 23(8), 1272 1288. $<$ https://doi.org/10.1016/j.tate.2006.06.001>

RichaRDs, J., \& LOCKHART, C. (1996). Reflective teaching in second language classroom. Cambridge: Cambridge University Press.

Ruiz-Corbella, M., Bautista-Cerro Ruiz, M. J., García-Blanco, M. (2019). Prácticas profesionales y la formación en competencias para la empleabilidad. Contextos Educativos, 23, 65-82. $<$ https://doi.org/10.18172/con.3560>

Smith, J. A., Flowers, P., \& Larkin, M. (2009). Interpretative phenomenological analysis: Theory, method, and research. London: SAGE.

Schön, D. A. (1983). The reflective practitioner: How professionals think in action. New York: Basic Books.

Yan, C., \& HE, C. (2010). Transforming the existing model of teaching practicum: a study of Chinese EFL student teachers' perceptions. Journal of Education for Teaching, 36(1), 57-73. <https://doi.org/10.1080/02607470903462065>

ZeICHNER, K. (1996). Designing educative practicum experiences for prospective teachers. In K. Zeichner, S. Melnick, \& M. L. Gomez (Eds.), Currents of reform in preservice teacher education (pp. 215-234). New York: Teachers College Press. 


\section{Appendix}

English translations of questions used in the final face-to-face interview (adapted from Andria et al., submitted).

\section{A. Questions about the host institution}

Please express your views regarding the following:

1. The welcome you received from your supervisor and mentor at the host institution

2. Your integration into the host institution

3. Structure and organization of the teaching placement

4. Physical space offered by the host institution for your professional development

5. Strong points of the host institution as a placement site

6. Suggestions for improvement

\section{B. Questions about the placement}

1. To what extent do you think this teaching placement enhanced your education/training as a language teacher of L2 Greek?

2. Do you think that teaching placements should be compulsory for all future teachers of Greek as an L2?

3. If you could start your teaching placement again now, what would you do differently?

\section{Questions on teaching Greek as a foreign language}

1. What expectations did you have about teaching Greek as an L2 before your placement? Were these expectations fulfilled?

2. What did you learn about teaching Greek as an L2 that you didn't expect before you started?

3. What did you learn as a result of your placement with regard to:

- teaching L2 vocabulary

- teaching L2 grammar

- teaching L2 pragmatic and sociocultural parameters

- the use of student's L1(s) or other languages that you used in the classroom to communicate with students

4. If you had previous experience with teaching Greek as an L2 in Greece, how was that different from teaching Greek as an L2 in this context?

5. What was your reaction to video-recording your teaching and the subsequent self-assessment and reflection tasks, both before and after you completed these tasks?

\section{Final appraisal / Concluding remarks}

Would you like to make any final comments about your overall reaction to your teaching placement experience or make any other general observations? 